\title{
Genital infections with Chlamydia trachomatis and Neisseria gonorrhoeae in Ghanaian women
}

\author{
CECILIA BENTSI,* C A KLUFIO,† PETER L PERINE, $\S$ THOMAS A BELL, $§$ \\ LINDA D CLES, $\S C$ MARK KOESTER, $\S$ AND SAN-PIN WANG $\uparrow$ \\ From the *Public Health Reference Laboratory and the †University of Ghana Medical School, Accra, \\ Ghana; the International Health Programs Office, Centers for Disease Control, Atlanta, Georgia; and \\ the Departments of §Epidemiology, I| Pediatrics, and \Pathobiology, University of Washington, Seattle, \\ Washington, USA
}

SUMMARY Women who attended the gynaecology clinic or were admitted to the postpartum ward of Korle Bu Hospital, Accra, Ghana were tested for infection with Chlamydia trachomatis and Neisseria gonorrhoeae. Eight $(4 \cdot 9 \%)$ of 162 gynaecological patients were infected with $C$ trachomatis and five $(3 \cdot 1 \%)$ with $N$ gonorrhoeae, and respective prevalences among 148 postpartum women were $7 \cdot 7 \%(3 / 39)$ and $3 \cdot 4 \%$ (5/148). Among 40 gynaecological patients who were not pregnant and whose principal complaint was of lower abdominal pain, $4(10 \%)$ were infected with $C$ trachomatis and none with $N$ gonorrhoeae. Antibodies against serovars D, E, F, and $\mathrm{G}$ were common, and three typable isolates were serovar G. $C$ trachomatis would appear to be more common than $N$ gonorrhoeae in obstetric and gynaecological patients in Ghana.

\section{Introduction}

Chlamydia trachomatis is probably the most common sexually transmitted pathogen in industrialised countries, ${ }^{1-3}$ and as shown in a few surveys it is also common in Africa. ${ }^{4-8}$ We undertook the study reported here to estimate the prevalence of genital infections with $C$ trachomatis and Neisseria gonorrhoeae among women living in a suburb of Accra, Ghana.

\section{Patients and methods}

We used calcium alginate swabs (Calgiswab type III, Inolex, Glenwood, Illinois, USA) to collect endocervical specimens for culture of $C$ trachomatis and $N$ gonorrhoeae from 162 newly registered, randomly selected women attending the gynaecology outpatient clinic at Korle Bu Hospital in Accra, and from 39 unselected postpartum women admitted to the hospital's maternity ward. Material from another 109 postpartum women was cultured for $N$ gonorrhoeae only. Using microimmunofluorescence we tested serum from 95 of these 109 women for IgG and IgM antibodies to $C$ trachomatis. ${ }^{9}$

Address for reprints: $\mathrm{Dr} C$ Bentsi, Public Health Reference Laboratory, P O Box 205, Korle-Bu, Accra, Ghana

Accepted for publication 24 March 1984
Demographic data of the patients were recorded, and a history of recent use of antimicrobials was sought. Korle $\mathrm{Bu}$ is the teaching hospital for the University of Ghana. It primarily serves self referred indigent patients from Accra and patients referred from nearby doctors and clinics. Thus the population is skewed towards a high prevalence of serious diseases.

Specimens for isolation of chlamydiae were placed immediately in sucrose phosphate transport media, frozen at $-70^{\circ} \mathrm{C}$, and transported on frozen carbon dioxide to Seattle, where they were cultured in McCoy cells treated with cycloheximide. ${ }^{10}$ Isolates of $C$ trachomatis, as identified by fluorescein conjugated monoclonal antibodies, ${ }^{10}$ were immunotyped in the indirect microimmunofluorescence test by immunising mice with the isolates." Presumptive identification of $N$ gonorrhoeae was confirmed by sugar utilisation tests, and isolates were tested for $\beta$-lactamase production with a chromogenic cephalosporm assay. ${ }^{12}$ We tried to locate and treat all women infected with $C$ trachomatis and $N$ gonorrhoeae.

\section{Results}

$C$ trachomatis was isolated from eight (4.9\%) of the 162 women attending the gynaecology clinic and from three $(7 \cdot 7 \%)$ of the 39 postpartum patients. $N$ gonorrhoeae was isolated from five $(3 \cdot 1 \%)$ of the 
162 gynaecological patients and five $(3 \cdot 4 \%)$ of 148 postpartum patients. Isolates from one postpartum patient and from one gynaecological patient produced $\beta$-lactamase. No patient was found to be infected simultaneously with $C$ trachomatis and $N$ gonorrhoeae.

The presenting complaints of the newly registered women attending the gynaecology clinic are listed in table I. Lower abdominal pain was the most common complaint among non-pregnant women and was accompanied by signs of pelvic inflammation (cervical motion tenderness and adnexal tenderness) in most. Three of these women, from whom no pathogens were isolated, had recently taken antimicrobials. $C$ trachomatis was isolated from four of them and $N$ gonorrhoeae was isolated from none.

TABLE I Prevalence of $C$ trachomatis and $N$ gonorrhoeae in randomly selected gynaecological patients at Korle Bu Hospital presenting with various complaints

\begin{tabular}{lll}
\hline & \multicolumn{2}{l}{ No (\%) infected with: } \\
\cline { 2 - 3 } Presenting complaint & C trachomatis & $N$ gonorrhoeae \\
\hline Related to pregnancy $(\mathrm{n}=44)$ & 0 & $2(4 \cdot 5)$ \\
Lower abdominal pain $(\mathrm{n}=40)$ & $4(10 \cdot 0)$ & 0 \\
Menstrual problems $(\mathrm{n}=29)$ & $3(10 \cdot 3)$ & $1(3 \cdot 4)$ \\
Vaginal discharge $(\mathrm{n}=11)$ & 0 & $1(9 \cdot 1)^{*}$ \\
Infertility $(\mathrm{n}=9)$ & $1(11 \cdot 1)$ & 0 \\
Other $(\mathrm{n}=29)$ & 0 & $1(3 \cdot 4)$ \\
Total $(\mathrm{n}=162)$ & $8(4 \cdot 9)$ & $5(3 \cdot 1)$ \\
\hline
\end{tabular}

*Producing $\beta$-lactamase.

Serum from $24(25 \cdot 3 \%)$ of the 95 postpartum women tested for antibodies to $C$ trachomatis reacted at a titre of at least 1/8; IgM to $C$ trachomatis was found in none of them. IgG titres ranged from $1 / 8$ to $1 / 512$. The antibody patterns against various serovar groups are listed in table II. A pattern of broadly reacting antibodies was most common. Serum from patients with specifically reacting antibodies reacted most commonly with the F,G group of serovars.

TABLE II Prevalence of antibodies to chlamydia in 95 postpartum women at a titre of $\geqslant 1 / 8$

\begin{tabular}{lc}
\hline Serovar group & $\begin{array}{l}\text { Number (\%) } \\
\text { of patients }\end{array}$ \\
\hline Broad reaction & $9(9 \cdot 5)$ \\
F,G & $8(8 \cdot 4)$ \\
D,E, $\mathrm{L}_{1}, \mathrm{~L}_{2}$ & $3(3 \cdot 2)$ \\
F,G, L, $\mathrm{L}_{2}$ & $1(1 \cdot 1)$ \\
H & $11(1 \cdot 1)$ \\
A, J,F,G & $11(1 \cdot 1)$ \\
No antibody & $11(1 \cdot 1)$ \\
\hline
\end{tabular}

Three isolates of $C$ trachomatis from women in the gynaecology clinic could be revived for immunotyping; all were serovar $\mathbf{G}$.

\section{Discussion}

This study shows that genital infections with $C$ trachomatis are more common than infections with $N$ gonorrhoeae in Ghanaian women. The $10 \%$ prevalence of $C$ trachomatis in women with lower abdominal pain suggests that it is an important cause of pelvic inflammatory disease (PID) in Ghana, perhaps more so than $N$ gonorrhoeae, which was isolated from none of the 40 women with this complaint $(p=0 \cdot 12$, Fisher's exact test $)$. Self administration of antimicrobials is common in Africa but was generally denied by these women and would therefore have had little influence on our results.

Serological data and immunotyping of isolates suggest that infection with F,G group serovars is most common. This group was the second most common in a survey of genital infections in Seattle, Washington. ${ }^{13}$ Conversely, the most common Seattle serovars ( $D$ and $E$ ) seem to be second in prevalence in Accra.

The prevalence of $C$ trachomatis $(7 \cdot 7 \%)$ in postpartum women in Accra is remarkably similar to that found $(5 \cdot 6 \%)$ in antenatal clinic patients in Nairobi, Kenya $^{5}$ and the $6.7 \%$ found in such patients in Fajara, The Gambia. ${ }^{8}$ Similarly, antenatal patients in Ibadan, Nigeria were found to have a comparable prevalence $(10.3 \%)$ of antibody titres of $\geqslant 1 / 16$ against serovars $\mathrm{D}$ to $\mathrm{K}$ compared with $9 \cdot 5 \%$ in this study. ${ }^{6}$

Infection with $N$ gonorrhoeae has been proposed as the cause for much of the infertility in Africa south of the Sahara, ${ }^{14}$ but our survey suggests that $C$ trachomatis may also be an important cause, as it is in the United States ${ }^{15-17}$ and Finland. ${ }^{18}$

The difficulties of storage and transportation of chlamydial specimens certainly leads to an underestimate of the prevalence of chlamydial infection in Accra. Cell culture technology is unlikely to be adequately available in Africa in the foreseeable future, but the recent availability of direct examination of specimens with monoclonal antibodies ${ }^{19}$ portends an improvement in the ability to diagnose these important agents of disease in developing countries.

This work was supported by a basic science research grant (61-3212) from the University of Washington and by grants AI-16222 and EY 00219 from the United States Public Health Service. TAB is the recipient of a Venereal Disease Research Fund postdoctoral fellowship from the American Social Health Association. 


\section{References}

1. Schachter J, Hanna L, Hill EC, et al. Are chlamydial infections the most prevalent venereal disease? JAMA 1975;231:1252-5.

2. Paavonen J, Saikku P, Vesterinen E, Meyer B, Vartiainen E, Saksela E. Genital chlamydial infections in patients attending a gynaecological outpatient clinic. British Journal of Venereal Diseases 1978;54:257-61.

3. Schachter J, Stoner E, Moncada J. Screening for chlamydial infections in women attending family planning clinics: evaluation of presumptive indicators for therapy. West $\mathrm{J}$ Med 1983; 138: 375-9.

4. Perine PL, Andersen AJ, Krause DW, et al. Diagnosis and treatment of lymphogranuloma venereum in Ethiopia. In: Nelson JD, Grassi C, eds. Current chemotherapy and infectious disease. Washington DC: American Society for Microbiology, 1980: $1280-2$.

5. Nsanze H, Waigwa SRN, Mirza N, Plummer F, Roclants $P$, Piot $P$. Chlamydial infections in selected populations in Kenya. In: Mårdh P-A, Holmes KK, Oriel JD, Piot P, Schachter J, eds. Chlamydial infections. Amsterdam: Elsevier Biomedical Press, 1982:421-4.

6. Darougar S, Forsey T, Osoba AO, Dives RJ, Adelusi B, Coker GO. Chlamydial genital infection in Ibadan, Nigeria: a seroepidemiological survey. British Journal of Venereal Diseases 1982;58:366-9.

7. Forsey T, Darougar S, Dines RJ, Wright DJM, Friedmann PS. Chlamydial genital infection in Addis Ababa, Ethiopia: a seroepidemiological survey. British Journal of Venereal Diseases 1982;58:370-3.

8. Mabey DCW, Whittle HC. Genital and neonatal infection in a trachoma endemic area. Lancet 1982; ii:300-1.

9. Wang S-P, Grayston JT, Kuo C-C, Alexander ER, Holmes KK. Serodiagnosis of Chlamydia trachomatis infection with the microimmunofluorescence test. In: Hobson D, Holmes KK, eds. Nongonococcal urethritis and related infections. Washington DC: American Society for Microbiology, 1977:237-48.
10. Stamm WE, Tam M, Koester M, Cles L. Detection of Chlamydia trachomatis inclusions in McCoy cell cultures with fluorescein-conjugated monoclonal antibodies. $J$ Clin Microbiol 1983; 17:666-8.

11. Wang SP, Kuo CC, Grayston JT. A simplified method for immunological typing of trachoma-inclusion conjunctivitislymphogranuloma venereum organisms. Infect Immun 1973; 7:356-60.

12. O'Callaghan $\mathbf{C H}$, Morris A, Kirby SM, Shingler AH. Novel method for detection of $\beta$-lactamase by using a chromogenic cephalosporin substrate. Antimicrob Agents Chemother 1972; 1:283-8.

13. Kuo CC, Wang SP, Holmes KK, Grayston JT. Immunotypes of Chlamydia trachomatis isolates in Seattle, Washington. Infect Immun 1983; 41:865-8.

14. WHO Scientific Group. Neisseria gonorrhoeae and gonococcal infections. WHO Tech Rep Ser 1978; No 616:42-4.

15. Moore DE, Foy HM, Daling JR, et al. Increased frequency of serum antibodies to Chlamydia trachomatis in infertility due to tubal disease. Lancet 1982; ii:574-7.

16. Jones RB, Ardery BR, Hui SL, Cleary RE. Correlation between serum antichlamydial antibodies and tubal factor as a cause of infertility. Fertil Steril 1982;38:553-8.

17. Gump DW, Gibson M, Ashikaga T. Evidence of prior pelvic inflammatory disease and its relationship to Chlamydia trachomatis antibody and intrauterine contraceptive device use in infertile women. Am J Obstet Gynecol 1983; 146:153-9.

18. Punnonen R, Terho $P$, Nikkanen V, Muerman O. Chlamydial serology in infertile women by immunofluorescence. Fertil Steril 1979; 31:656-9.

19. Nowinski RC, Tam MR, Goldstein LC, et al. Monoclonal antibodies for diagnosis of infectious diseases in humans. Science 1983;219:637-44. 